\title{
クロロプレンゴム用高温加硫促進剤
}

\author{
（昭和49年10月17日 受理）
}

\section{酒向 泰蔵苂・箕 浦 有二*2}

\begin{abstract}
要 旨 $N, N^{\prime}$-ビス $\left(\beta\right.$-ヒドロキシルェチル)エチレンジアミンと二硫化炭素との反応により $N, N^{\prime}-エ チ$ レンビス（チアゾリジン-2-チオン）(以下 EBT と略す）を合成し，その化学的性質を調べた。更にこの EBTをクロロプレンゴムへ添加し，その高温加硫促進性を検討した。 その結果, EBT は酸性溶媒中でも安 定であり，化学的反応性も低いものと考えられた。一方クロロプレンゴムへの高温加硫促進性は顕著な効果 を示し，かつ $140^{\circ} \mathrm{C}$ 以下において，初期加硫が認められず加工安定性の良い優れた高温加硫促進剤であるこ とが諗められた。
\end{abstract}

\section{1. 緒言}

クロロプレンゴム, エピクロルヒドリンゴム及び塩素 化プチルゴムなどの含塩素系合成ゴムは耐油性，耐溶剂 性，難燃性などに大きな特徽を有している，しかしこれ らの合成ゴムは, 加工性, 特に加硫という点で天然ゴム, SBRなどよりむ困難な点を有している，特に近年射出成 形などの高温短時間連続加硫方式が各ゴム加エメーカー において採用されてきた，ハロゲン化合成ゴムにおいて は高温短時間加硫用の満足すべき加硫促進剤がなく，そ の開発が必要とされている。一般に高温加硫促進凧とな るためには以下の条件を満足する必要がある。

1) 高温 $\left(200^{\circ} \mathrm{C}\right.$ 以）では急速な加硫促進性を有して いても，通常の加硫温度 $\left(140 \sim 160^{\circ} \mathrm{C}\right)$ では加硫し ない.

2) 引張応力, 引張強さ $\left(T_{B}\right)$ などの物性值が通常の 加硫温度で加硫した場合よりも劣らないこと.

3）過加硫の場合でも大きな加硫もどりがなく，平坦 加硫を起こすものであることなどである.

筆者らは， $N, N^{\prime}$-エチレンビス（チアゾリジン-2-チ オン) を合成し，その化学的性質を検討したが同時にク ロロプレンゴムに対し，この化合物が上記1）～3)を满足 する高温加硫促進肪であることを見いだしたのでここに 報告する。

\section{2. 実 験}

\section{1 試薬}

$\mathrm{N}, \mathrm{N}^{\prime}$-エチレンビス（ $\beta$-ヒドロキシエチル）エチレン

${ }^{* 1}$ 大内新興化学工業(

(厂174 東京都板橋区前野町 3-37-1)

*2 大阪市立大学原子力基礎研究所 (宁558 大阪市住吉区杉本町 457)
ジアミンは製鉄化学製のものをメタノールで再結晶して 用いた. $\left(\mathrm{mp} 101 \sim 101.5^{\circ} \mathrm{C}\right)$

二硫化炭素，ジメチルホルムアミド，塩酸，ヨウ化メ チル，過酸化水素注市販特級品をそのまま用いた。

\subsection{EBT $の$ 合成}

$\mathrm{N}, \mathrm{N}^{\prime}$-エチレンビス ( $\beta$-ヒドロキシエチル) エチレン ジアミン $60 \mathrm{~g}$ (0.4モル)を $15 \%$ の水酸化ナトリウム水溶 液 $500 \mathrm{~g}$ に溶加した溶液をかきませておきこれれ二硫 化炭素80 g (1.05モル) を滴下して 8 時間， $40 \sim 45{ }^{\circ} \mathrm{Cで}$ かきまぜた後, 沈殿物をろ過, 水洗.乾燥して, 㚒白色粉 末 $21.2 \mathrm{~g}$ を得た.これをDMFより再結晶して白色針状 結晶 $17.2 \mathrm{~g}\left(\mathrm{mp} 259 \sim 261^{\circ} \mathrm{C}\right.$ )のものを得た. 元素分析 值, 赤外吸収スペクトルより $\mathrm{N}, \mathrm{N}^{\prime}$ ーエチレンビス（チ アジリジンー2 -チオン) [EBT] であることを確誌した.

\section{元素分析值}

\begin{tabular}{|c|c|c|c|c|}
\hline & $\mathrm{C}(\%)$ & $\mathbf{H}(\%)$ & $\mathbf{N}(\%)$ & $\mathrm{S}(\%)^{* 1}$ \\
\hline 計算値 & 36.14 & 4.61 & 10.46 & 47.6 \\
\hline 測定值 *2 & 36.33 & 4.57 & 10.59 & 48.5 \\
\hline
\end{tabular}

すなわち，EBT の元素分析値が分子式 $\mathrm{C}_{8} \mathrm{H}_{12} \mathrm{~N}_{2} \mathrm{~S}_{4}$ に一 致すること及び赤外吸収スペクトル（図 1)より， $\mathrm{N}$ ，

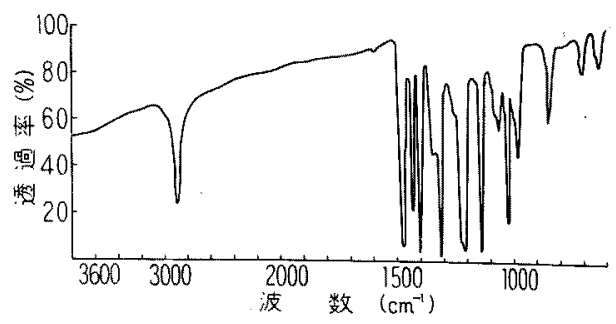

困 1 EBT の赤外吸収スペクトル 
N'ービス ( $\beta$-ヒドロキシェチル) エチレンジァミンの $v_{N H} 3300 \mathrm{~cm}^{-1}$ の吸收が消失し, 新たに>N-C=Sの $v_{\mathrm{C}=\mathrm{s}}$, $633 \mathrm{~cm}^{-1}, 860 \mathrm{~cm}^{-1}$ に認められたことより目的物であ ることを確認した. 更に2-アミノェタノールがアルカリ の存在下で二硫化炭素と反応して，チアジリジンー 2-チ オンを生成する゙場合と同様に，この場合も次に示す反 応式により EBTが生成したことを示するのである。

$\mathrm{HOCH}_{2} \mathrm{CH}_{2} \mathrm{NHCH}_{2} \mathrm{CH}_{2} \mathrm{NHCH}_{2} \mathrm{CH}_{2} \mathrm{OH}+\mathrm{CS}_{2}$<smiles>CSC(=S)N(CCO[NH3+])CCC1SCCN1C(=S)SCC(C)C</smiles>

\subsection{EBT $の$ 化学的性質の検討}

EBT に $\mathrm{HCl}, \mathrm{CH}_{3} \mathrm{I}, \mathrm{H}_{2} \mathrm{O}_{2}$ を作用させて, $>\mathrm{N}-\mathrm{C}(\mathrm{S}) \mathrm{S}$ に执ける > N-, 一 C $(\mathrm{S}) \mathrm{S}$ の性質を調べた。

\section{4 クロロプレンゴムに対する加硫促進効果}

クロロプレンゴムとしてネオプレン一W（昭和ネオプ レン)を用いた. 加硫促進効果は JSR 形キュラストメー ター（今中機械製）により $140^{\circ} \mathrm{C}$ 200 $20{ }^{\circ}$ の加硫促進を観 測し，これよりこの温度に扔ける最適加硫時間を測定し た. 加硫物の物性については $200^{\circ} \mathrm{Cで}$ 加硫したものについ て, 東洋ボールドウイン製のテンシロン引張試験機によ り引張強さ $\left(T_{B}\right)$, 伸び $\left(E_{B}\right)$ 及び引張応力 $\left(M_{100}, M_{300}\right)$ を測定した.これら一連のデータより市販のクロロプレ ンゴム用加硫促進凨, エチレンチオウレア, トリメチル チオウレアと EBT との比較を行った.

\section{3. 実 験 結 果}

\subsection{EBT $の$ 化学的性質}

3.1 .1 EBT と塩酸との反応 EBT に大過剩の湿塩

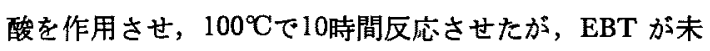
反応物として回収され，アミンの四級塩もまたその開環 反応生成物も得られなかった。

3.1 .2 EBT $と \mathbf{C H}_{3} \mathbf{I}$ टの反応 EBT $0.4495 \mathrm{~g}(0.0$

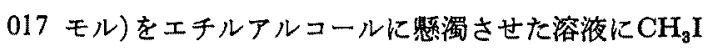
$11.5 \mathrm{ml}$ (EBT の約10倍モル量)を加えて室温下で24時 閒かきませた. かきまぜ後, 黄色結晶物 $0.742 \mathrm{~g}$ を得 た. この結晶物 $\left(\mathrm{mp} 260 \sim 267^{\circ} \mathrm{C}\right)$ の元素分析值は次の とおりりであった.

\begin{tabular}{ccrrr} 
& $\mathrm{C}(\%)$ & $\mathrm{H}(\%)$ & $\mathrm{N}(\%)$ & $\mathrm{S}(\%)$ \\
\hline 测定值 & 22.09 & 3.42 & 4.97 & 23.5 \\
\hline 計算值 & 21.90 & 3.28 & 5.11 & 23.4 \\
\hline$* 1$ & $\begin{array}{l}\text { EBT } \text { に } 2 \text { 分子の } \\
\mathrm{I}_{2} \text { の值. }\end{array}$ & & $\mathrm{CH}_{3} \mathrm{I}$ が付加した & $\mathrm{C}_{10} \mathrm{H}_{18} \mathrm{~N}_{2} \mathrm{~S}_{4}$ \\
& & &
\end{tabular}

この結果より $\mathrm{EBT}$ と $\mathrm{CH}_{3} \mathrm{I}$ との反応は次のよ5に考 えられた.

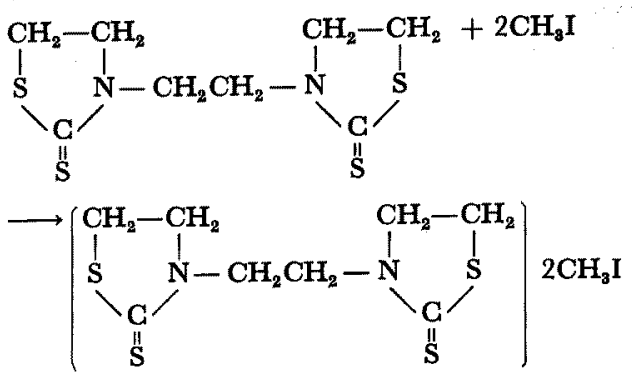

3.1.3 $\mathrm{H}_{2} \mathrm{O}_{2}$ との反応 $\mathrm{EBT} 5.757 \mathrm{~g}(0.0235$ モル)を $\mathrm{CHCl}_{3} 20 \mathrm{ml}$ に慗濁させ，これに $30 \% \mathrm{H}_{2} \mathrm{O}_{2}, 5.142 \mathrm{~g}$ を 室温下に滴下した. 約11時間, 室温下でかきませた後, 沈殿物をろ別して，白色粉未 $3.728 \mathrm{~g}$ （I ）を得た．更に ろ液を重炭酸ナトリウムで中和した後, メタノール可溶 部と（II）と不溶部（III）に分けた. 各部の性状を以下に示 す.

[I] 白色粉未 $\mathrm{mp} 259 \sim 261^{\circ} \mathrm{C} \quad 3.73 \mathrm{~g}$

[II] 淡黄色粉末 $\mathrm{mp} 136 \sim 138^{\circ} \mathrm{C} \quad 0.06 \mathrm{~g}$

[III] 黄色粘ちょ5物 $0.05 \mathrm{~g}$

〔I]は融点1Rスペクトルより末反応物の EBT で あることが判明した．しかし［II]，[II]はTLCより 数種の混合物よりなり明確に同定できなかった。、いずれ にしろ， EBT は $\mathrm{H}_{2} \mathrm{O}_{2}$ と反応せず，大部分が末反応物 であった.

3.2 EBT によるクロロプレンゴムの加硫

表 1 配 合 表

\begin{tabular}{lrrrrr}
\hline & No. 1 & No. 2 & No. 3 & No. 4 & No. 5 \\
\hline $\mathrm{CR}(\mathrm{W}-$ タイプ $)$ & 100 & 100 & 100 & 100 & 100 \\
$\mathrm{ZnO}$ & 5 & 5 & 5 & 5 & 5 \\
$\mathrm{MgO}$ & 4 & 4 & 4 & 4 & 4 \\
ステアリン酸 & 1 & 1 & 1 & 1 & 1 \\
$\mathrm{EBT}$ & 0.5 & 1.0 & 2.0 & - & - \\
エチレンチオウレア- & - & - & 0.5 & - \\
トリメチルチオ & - & - & - & - & 0.5 \\
ウレア & & & & & \\
\hline
\end{tabular}

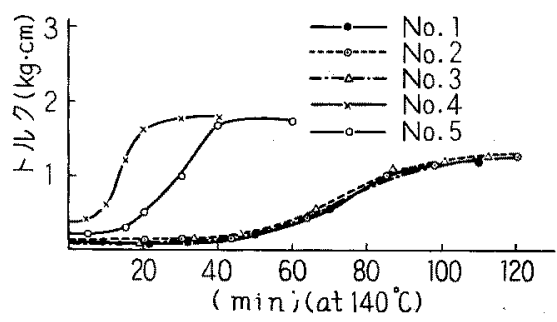

図 2 加硫時間 


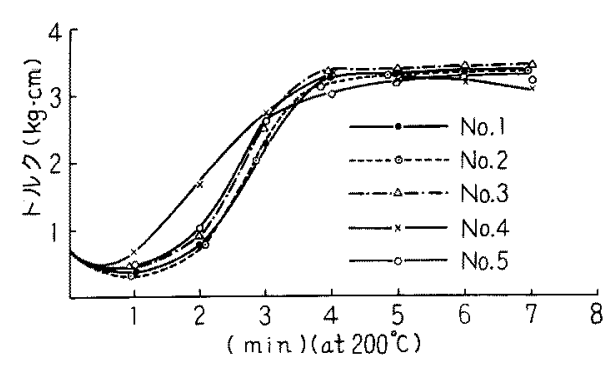

図 3 加偣時間

表 2 最適加硫時間 (min)

\begin{tabular}{ccc}
\hline 試 料番 号 & $\begin{array}{c}\text { 加 硫 } \\
\end{array}$ & $\begin{array}{c}\text { 温 度 } \\
200^{\circ} \mathrm{C}\end{array}$ \\
\hline No. 1 & 90 & 4.0 \\
No. 2 & 88 & 3.5 \\
No. 3 & 88 & 3.5 \\
No. 4 & 16 & 3.8 \\
No. 5 & 40 & 4.0 \\
\hline
\end{tabular}

表 1 の配合に基づき観測した加硫曲線を図 2，図 3 に 示した，図2, 図3より各温度に括ける最適加硫時間を 求めると表 2 のデータが得られた.

\section{4. 考察}

エチルチアゾリジンー2-チオンは次のよ5な反応をす ることが知られている2).

$$
\underset{\mathrm{CH}_{2}-\mathrm{S}}{\stackrel{\mathrm{CH}_{2}-\mathrm{NH}}{L}}>\mathrm{C}=\mathrm{S} \frac{\mathrm{HCl}}{\text { in } \mathrm{H}_{2} \mathrm{O}} \stackrel{\stackrel{\mathrm{CH}_{2}}{\mathrm{C}}-\mathrm{SH}}{\mathrm{CH}_{2}-\mathrm{NH}_{2}}
$$

しかしながら EBT は $\mathrm{HCl}$ と加熱してもほとんど反 応しなかった. 更に $\mathrm{H}_{2} \mathrm{O}_{2}$ と反応させても大部分が末反 応物として回収され，安定なスルホキシドは得られなか った. 更に $\mathrm{CH}_{3} \mathrm{I}$ とはその付加体を作るが，しかも通常 よく知られている次式に類する反応はほとんど起こって いなかった.

$$
\begin{aligned}
& \mathrm{R}-\mathrm{S}-\mathrm{R}^{\prime}+\mathrm{CH}_{3} \mathrm{I} \longrightarrow \mathrm{R}-\mathrm{S}-\mathrm{CH}_{3}+\mathrm{R}^{\prime} \mathrm{I} \\
& \mathrm{R}-\mathrm{S}-\mathrm{CH}_{3}+\mathrm{CH}_{3} \mathrm{I} \longrightarrow \mathrm{CH}_{3}-\mathrm{S}-\mathrm{CH}_{3}+\mathrm{RI}
\end{aligned}
$$

EBTについては次の反応であった。

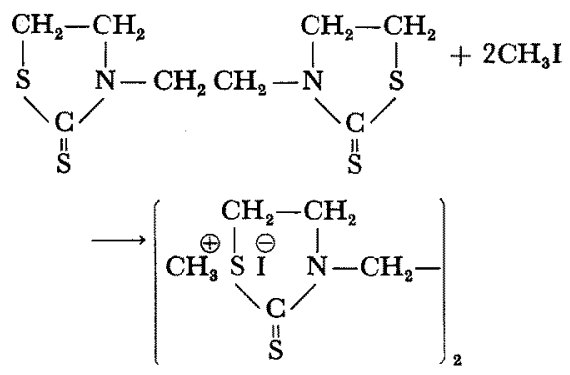

このことは EBT のC-S-C の結合は求核試薬に対し て通常のスルフィド結合より安定であると推測された.

このことはクロロプレンゴムを求核試薬と考える場 合，その加硫速度に大いに影響することが考えられる。 すなわちエチレンチオウレアを加硫促進㓮として用いた ときのクロロプレンゴムの加硫は次のよ5に考えられて いる゙?

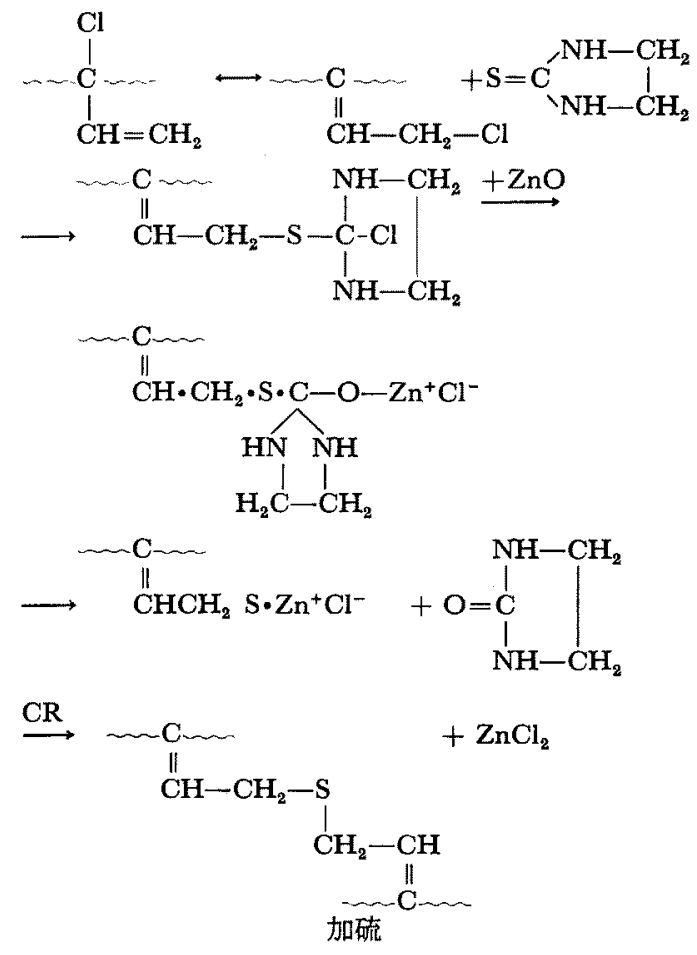

上式のように加硫反応を考えるとき，加硫剤(又は加硫 促進剂) はアミンの塩基性あるいはチオケトンの反応性 に大いに関倸することが容易に推测される、EBT は先 にも述べたように，Nの塩基性は非常に弱く（酸と処理

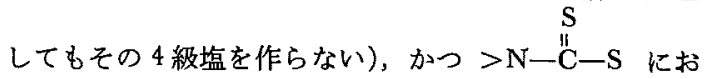
けるチオエーテル基も比較的安定である。このことから クロロプレンゴムに EBTを涯加したときその架橋反応 は通常の条件では非常に緩慢であることが考えられる。 このことは図 2 の $140^{\circ} \mathrm{C}$ の加硫曲線からも認められるよ らにこの温度では架橋反応は起こりにくい．しかし図 3 の加硫曲線をみると明らかなように $200{ }^{\circ} \mathrm{C} に$ 加熱する と，急速な架橋反応を呈することが認められる。

また EBT が市販の加硫促進剤に比べて著しい特徽を

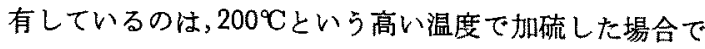
も過加硫による加硫もどりを起こしていないことであ る. また物性的にみても $T_{B}, E_{B}, M_{100}, M_{300}$ が，エチレ 
表 3 加硫時間による物性試験

加硫温度 $200^{\circ} \mathrm{C}$

\begin{tabular}{|c|c|c|c|c|c|c|}
\hline No. & 妿 硫 & $\begin{array}{c}\text { 加硫時間 } \\
(\mathrm{min})\end{array}$ & $\begin{array}{c}T_{B} \\
\left(\mathrm{~kg} / \mathrm{cm}^{2}\right)\end{array}$ & $\begin{array}{c}E_{B} \\
(\%)\end{array}$ & $\begin{array}{c}M_{100} \\
\left(\mathrm{~kg} / \mathrm{cm}^{2}\right)\end{array}$ & $\begin{array}{c}M_{300} \\
\left(\mathrm{~kg} / \mathrm{cm}^{2}\right)\end{array}$ \\
\hline 1 & $\mathrm{EBT}$ & $\begin{array}{r}3 \\
5 \\
7 \\
10\end{array}$ & $\begin{array}{l}135 \\
161 \\
164 \\
175\end{array}$ & $\begin{array}{r}1000 \\
850 \\
810 \\
810\end{array}$ & $\begin{array}{l}8 \\
10 \\
11 \\
11\end{array}$ & $\begin{array}{l}13 \\
18 \\
20 \\
21\end{array}$ \\
\hline 2 & EBT & $\begin{array}{r}3 \\
5 \\
7 \\
10\end{array}$ & $\begin{array}{l}156 \\
152 \\
138 \\
135\end{array}$ & $\begin{array}{l}830 \\
700 \\
690 \\
670\end{array}$ & $\begin{array}{l}10 \\
12 \\
12 \\
12\end{array}$ & $\begin{array}{l}20 \\
24 \\
23 \\
25\end{array}$ \\
\hline 3 & EBT & $\begin{array}{r}3 \\
5 \\
7 \\
10\end{array}$ & $\begin{array}{l}109 \\
111 \\
124 \\
105\end{array}$ & $\begin{array}{l}680 \\
600 \\
610 \\
580\end{array}$ & $\begin{array}{l}12 \\
14 \\
14 \\
14\end{array}$ & $\begin{array}{l}24 \\
30 \\
29 \\
30\end{array}$ \\
\hline 4 & $\begin{array}{l}\text { エチ } \\
\text { ンチ才 } \\
\text { ウレア }\end{array}$ & $\begin{array}{l}1 \\
3 \\
5 \\
7\end{array}$ & $\begin{array}{l}135 \\
111 \\
108 \\
128\end{array}$ & $\begin{array}{l}890 \\
650 \\
640 \\
680\end{array}$ & $\begin{array}{r}8 \\
11 \\
12 \\
11\end{array}$ & $\begin{array}{l}15 \\
22 \\
23 \\
23\end{array}$ \\
\hline 5 & $\begin{array}{l}\text { トリメ } \\
\text { チルチ } \\
\text { オウレ } \\
\text { ア }\end{array}$ & $\begin{array}{l}1 \\
3 \\
5 \\
7\end{array}$ & $\begin{array}{r}35 \\
116 \\
109 \\
109\end{array}$ & $\begin{array}{l}770 \\
710 \\
690 \\
690\end{array}$ & $\begin{array}{r}4 \\
10 \\
11 \\
11\end{array}$ & $\begin{array}{r}9 \\
18 \\
20 \\
21\end{array}$ \\
\hline
\end{tabular}

ンチオウレアと比較して，大差ないことが次の表 3 より 明らかである。

こうしたことより， EBT は射出成形時の高温加硫促 進䬉として優れているといえる.

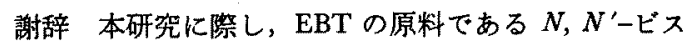
( $\beta$-ヒドロキシェチル) エチレンジアミンを提供していた だいた製鉄化学侏に感謝の意を表します。

本報文は昭和45年 5 月20日，日本ゴム拹会第37回総会 研究発表講演会に発表したものである.

\section{文献}

1) W. Theilheimer: Synthetic Methods 19693 (1965)

2) S. Gabriel: Ber, 22 1139(1889)

3) The Vanderbilt Rubber Handbook 126(1968)

\section{HIGH TEMPERATURE CURING AGENT FOR CHLOROPRENE RUBBER}

Taizo SAKO*1, Yuji MINOURA*2, (*1Ouchi Shinko Chemical Industry Co. Ltd., 337-I, Maeno-cho, Itabashiku, Tokyo, 174, Japan; *2Osaka City University, 459 Sugimotocho, Sumiyoshi-ku, Osaka, 558, Japan)

$N, N^{\prime}$-ethylene bis (thiazolidine-2-thione) [EBT] was prepared from $N, N^{\prime}$ - bis ( $\beta$-hydroxyethyl) ethylenediamine and carbon disulfide and its chemical reactivities were investigated.

The results showed that EBT did not react with hydrogen chloride and hydrogen peroxide, but reacted with methyl iodide to give an $\mathrm{EBT}-\mathrm{CH}_{3} \mathrm{I}$ adduct. That is, it is thought that EBT has a low reactivity with neucleophilic reagents. Further, the ability of EBT as curing agent for chloroprene rubber (CR) was studied, and it was found that $\mathrm{CR}$ was not cured at $140^{\circ} \mathrm{C}$ by EBT but cured at $200^{\circ} \mathrm{C}$ and EBT had a plateau effect.

Therefore, EBT is a new good high temperature curing agent for CR.

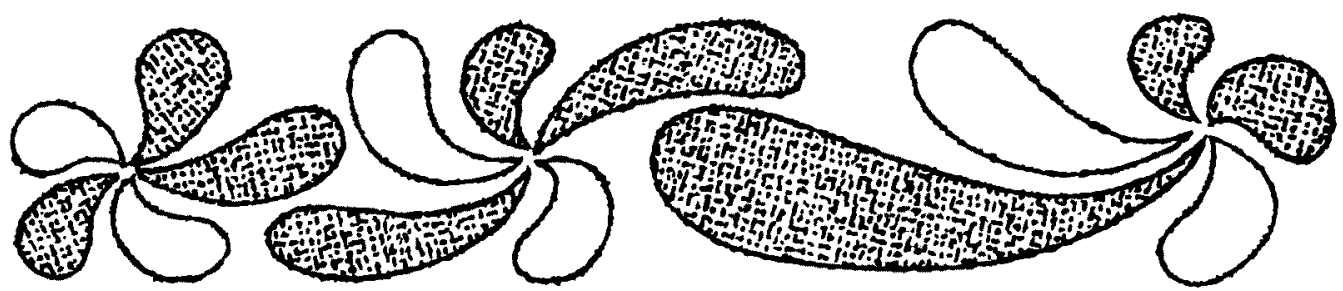

